DOI: https://doi.org/10.35387/ucj.2(4).2021.47-54

MARIIA HULIAIEVA

\title{
ADULT EDUCATION PROFESSIONALIZATION IN GERMANY: ESSENTIAL SCIENTIFIC AND HISTORICAL DISCOURSE
}

\begin{abstract}
The given article analyses the theories of professionalization, which conceptually define the essence and content of andragogy training in Germany. The research used general scientific (analysis, synthesis, generalization, systematization of collected material) and search and bibliographic methods (study of archival sources, legislation, historical, genetic and chronological analysis, which traced the understanding and formation of adult education evolution in Germany), as well as methods of definitive, theoretical and methodological, system-structural, structural and functional, and structural-logical analysis. It was found that the professionalism of the staff is a prerequisite for the functioning in social activity of any branch and sphere. It is proved that in Germany this issue has become especially relevant and is considered exclusively in the context of professionalization theories for a particular educational field. Theoretical principles and directions, models (mechanisms) and levels of professionalization are generalized; the essence of andragogy professionalism and professional habit of adult education specialist is specified. The main historical milestones in the understanding, interpretation and approval of the idea of adult education professionalization in Germany are highlighted. The scientific (theoretical and methodological, philosophical) and historical and practical (factual) approaches to the developed idea of professionalization in the outlined educational field are revealed. The existence and functioning at the qualitative level in the system of academic training for adult education specialists as a separate direction in the professionalization of the researched field is stated. Further research is necessary on the issues of antinomies and paradoxes observed within the actual field of adult education and its institutions, which is naturally reflected in the requirements for training, knowledge, skills and qualities of andragogy specialists.
\end{abstract}

Key words: adult education, andragogue, vocational training, professionalism, adult education professionalization in Germany.

\section{ПРОФЕСІОНАЛІЗАЦІЯ СФЕРИ ОСВІТИ ДОРОСЛИХ У НІМЕЧЧИНІ: СУТНІСНИЙ НАУКОВО-ІСТОРИЧНИЙ ДИСКУРС}

Анотація. У статті проаналізовано теорії професіоналізації, які концептуально визначають сутність і зміст професійної підготовки андрагогів у Німеччині. Для дослідження використано загальнонаукові (аналіз, синтез, узагальнення, систематизація зібраного матеріалу) та пошуковобібліографічні (вивчення архівних джерел, законодавчих актів, історико-генетичний і хронологічний аналіз, що дозволили простежити еволюцію розуміння та становлення системи професіоналізації освіти дорослих в Німеччині) методи, а також методи дефінітивного, теоретикометодологічного, системно-структурного, структурно-функціонального та структурно-логічного аналізу. З'ясовано, що професіоналізм персоналу є обов'язковою умовою функціонування будь-якої галузі та сфери соціальної діяльності. Доведено, що в Німеччині че питання набуло особливої актуальності і розглядається винятково в контексті теорій професіоналізації визначеної освітньої сфери. Узагальнено теоретичні засади та напрями, моделі (механізми) та рівні професіоналізації, уточнено сутність професіоналізму андрагога та професійного габітусу фахівця освіти дорослих. Висвітлено основні історичні віхи в розумінні, трактуванні та утвердженні ідеї професіоналізації сфери освіти дорослих у Німеччині. Розкрито науковий (теоретико-методологічний, філософський) та історико-практичний (Фактичний) підходи до закріплення ідеї професіоналізації окресленої освітньої галузі. Констатовано наявність та функціонування на якісному рівні системи академічної підготовки фахівців для освіти дорослих як окремого напрямку у професіоналізації досліджуваної сфери. Подальшого дослідження потребують питання антиномій і парадоксів, що спостерігаються всередині власне галузі освіти дорослих та їі інституцій, що закономірно відображається на вимогах до професійної підготовки, знань, умінь та якостей фахівців-андрагогів.

Ключові слова: освіта дорослих, андрагог, професійна підготовка, професіоналізм, професіоналізація освіти дорослих в Німеччині.

Introduction. The adult education system in Germany employs a large number of professionals i.e. managers, planners, teachers, consultants and staff in adult / continuing educa- tion who are fully responsible for the organizational support and functioning of adult education as a field. This circumstance corresponds to the diversity of service providers in the field 
of continuing education, as well as the professional field variety, in which there is no single professional title (position). The purposes, functions, roles and positions of continuing education staff are diverse and vary. The more media-related profiles, the more complex the terminology, with different job titles in this area. They are independent from departments, according to the facility management, teaching staff, course management, and relevant areas of activity. For educators who work with adults, there are the following designations i.e. fulltime teaching staff, manager, lecturer, teacher, head of courses, instructor, educational facilitator, moderator, trainer, training instructor, team member, advisor, consultant, etc. However, if you look closely, these are partial denotations of tasks, where each participator makes the process of activities differentiation in adult education / continuing education visible (Kühn, Brandt, Robak, Pohlmann \& Dust, 2015).

The access to employment in the continuing education system is not formally regulated, and many of the workers involved come to work by accident. In particular, regarding the case of the lecturers' selection, the criteria are more relevant than the pedagogical qualification, the relevant qualification in a particular subject and the social competence of the applicant (Koscheck, Weiland \& Ditschek, 2012). In terms of formal educational qualifications, there is a high degree of academicization which means that $73 \%$ have a degree. However, it is interesting to note that the educational level is very heterogeneous and not necessarily present: $19 \%$ received pedagogical education, another $19 \%$ have other education, $21 \%$ participated in provider training courses, $28 \%$ received «other education» (although the question about what other education is left open here) and 34\% have no professional training) (Ambos, Koscheck \& Martin, 2014).

Since, in the context of the discussion on the quality of continuing education, such a question is considered very critically, and there is a convincing argument for the importance of lecturers having the necessary pedagogical competencies to interact with adult students. Accordingly, the following requirements are the most important in the pedagogical staff training of the adult education field they are as follows «1) professionalization, as there is no basic practical training, sufficient and effective training program and development of an appropriate work profile; 2) improving the social protection of educational institutions employees for adults; 3) professional development of teachers on organizational issues (public relations problems, organizational development, marketing and financial planning), as well as legal and juridical competencies; 4) ensuring the quality of education by developing pedagogical competencies and raising the level of qualifications, by implementing appropriate internal organizational measures and involving pedagogically active persons in training; 5 ) enriching pedagogical activities with counselling and moderation skills» (Meisel \& Dollhausen, 2006; Kraft, 2007).

Until recently, these requirements have not been properly evaluated in adult education across Europe. Currently, they are given considerable attention in the system of adult teachers' education and training.

According to the vast majority of German researchers who have studied the adult education development and providing it with highly qualified personnel as a necessary element of progress due to the whole socio-economic situation in the country, without the professionalization progress doctrine and achievements systematization is impossible.

The aim of the study. Therefore, in the context of our study, we consider it necessary to analyse the professionalization theories, which conceptually determine the nature and the content of andragogues professional training in Germany.

Theoretical basis and research methods. During the formation of the source base in the research there was systematized a group of German scientists works who developed their scientific research in the field of professionalization, in particular, such as: W. Schulenberg, G. Holzapfel, R. Vath, H. Hartmann and M. Hartmann, R. Arnold, B. Koring, D.H. Jütting, H. Tietgens, S. Kade, A. Combe and W. Helsper, D. Nittel, P. Faulstich, S. Kraft, R. Zech and others. As a result, after elaboration their approaches to the definition of the category "professionalization» and the disclosure of its subject content, it was found that German authors understand professionalization in different 
senses i.e. pedagogical, acmeological, socioeconomic, sociological, sociological-stratifying.

According to M. Heidenreich, professionalization means the process by which vocational education and the development of the professional knowledge base are systematized and institutionalized, and specific areas of activity are reserved for profession representatives (Heidenreich, 1999).

H. Mieg (2006) considers the concept of professionalization in narrow and broad senses. In a narrow sense, it is the process of developing a professional group in relation to the profession, i.e. a professional group that has some autonomy in the field of performance control; and, more broadly meaning is the transition to paid work in compliance with certain mandatory quality standards.

Characteristics of the profession formation (according to the classical sociology of professionalization) are as follows: 1) standardized education, trends in academicization; 2) formation of a widespread knowledge base; 3) the formation of associations and professional policies to achieve and ensure professional goals, as well as to articulate self-awareness (consolidation of the profession); 4) formation of access to channels for activity spheres within the framework of professional policy (monopolization, hierarchy and segmentation in professional and special branches; autonomy, selfcontrol, delimitation from non-professional / non-specialized actions), «market closure» i.e. the profession decides who is allowed to appear on market as a provider or who is excluded from it due to the lack of standards (Arnold \& Lermen, 2012).

The essence of professionalization is revealed in the structural characteristics (specific knowledge base, theoretical and abstract expert knowledge and practical knowledge or knowledge from experience, practice, organizational association of actors operating in the field, professional standards, training programs and field access control) and motives (economic interests, ensuring the quality of services, improving social status, further development of the knowledge base, transparency of services) professionalization of academic professions.

There are two models of professionalization in the German subject literature, they are as follows 1) professionalization «bottom-up», i.e. the professional group is the subject and carri- er of the process; 2) professionalization « topdown» where the professional group is the object of state regulation (Hartz, 2004; Klingovsky, 2012; Kraft, Seitter \& Kollewe, 2009). Bottom-up professionalism is usually attributed to the Anglo-American sphere of use, while top-down professionalism is considered to a continental European model.

The interpretation of professionalism at the individual level, which German scholars consider as the development of professional (a holistic system of dispositions of perception, evaluation, classification and actions of the individual, the result of experience and internalization of individual social structures of unconscious nature habit) is important for our study. At the present stage, a separate scientific school has been formed, which representatives study the issues of professionalization of adult education in Germany and training of staff to meet the needs in this field. Among the most famous authors we can identify W. Gieseke, R. Tippelt, C. Buschle, R. Egetenmeyer, S. Lattke, I. Schuessler.

Results. Professionalization defines both achieving a certain level of competence and the behaviour and actions of individuals. Indicative frameworks for individual professionalization are provided by such concepts as the knowledge base presented by professional organizations, training courses, standards and criteria of relevant professional actions, ethical ideas, etc. They are an expression of internal professional practice, internal professional understanding and serve as a basis for people to think about their practice (professional socialization, internalized control, etc.).

The essence of the individual level of professionalization German scientists reveal through the content of the concept «professionalism». In everyday language, "professional» or «professionalism» means the ability and systematic and effective performance of activities. Accordingly, «unprofessional» refers to arbitrary actions and deeds in which someone is guided by their (subjective) feelings. There is no more detailed definition in the everyday language of professionalism or professional action and behaviour. The semantic feature in the use of language is that professionalism is not tied to professions and professional development.

In professional contexts, on the other hand, professionalism refers to certain technical cri- 
teria and standards, as well as to a certain knowledge base, which is available only to persons with appropriate training. Only this knowledge allows you to perform the professional activities at a professional level. Professional activity in the narrower sense is an activity that is perceived by the relevant group of colleagues related to formal and informal standards. It is characterized by a reference to a specific knowledge base that provides explanatory and practical knowledge, as well as a focus on specific criteria and standards that are considered decisive for the proper individuals' behaviour in a given field of activity (SchmidtLauff, 2008).

Realizing the specifics of the andragogy profession, the reflections of German scholars on the issue of «professionalism without a profession» are significant (Meuser, 2005; Mieg \& Pfadenhauer, 2003); Schmidt-Lauff \& Gieseke, 2014). A special feature of approaches focused primarily on individual professionalization and everyday language understanding in professionalization is that they do not consider, for example, the development of legally binding standards, as well as training and issuance of professional certificates as a prerequisite for professionalization. The latter, therefore, may also be based on the "self-commitment» of those working in the field to professional activities and the development of relevant competencies. Although in this case professionalization is still based on institutions (on a professional organization, on a certain knowledge base and on professional standards), it is not necessarily related to the responsibility statement of a certain group of participants for a particular field in activity and for solving problems and exclusive professional access to the field in activity (striking examples: managers, mentors, evaluators).

The goals of professionalization are likely to be set in the performers' interests who, in exchange with others, agree on quality standards for professional activities, which serve as a basis for reflection on their practice and provide some transparency to the outside world.

Thus, professionalization is understood as a strategy by which a professional group seeks to increase its social status, and the profession takes its form.
Accordingly, each field of activity, strives for professionalization, which entails a number of advantages. It is also applied to adult education. It should be noted that the issue of professionalization in this field of education, as evidenced by the analysis of German literature, is one of the most discussed and debatable.

The most profound and comprehensive analysis of the professionalization issue of adult education was carried out by Wiltrud Gieseke, who organized and systematized the results of scientific research by Overman, Kade, Arnold, Coring, Siebert, Jagenlauf, Knol, Dickman and others. The researcher investigated the institutional development for adult education and training, the theory of professionalization, the mechanism and sources of teachers for adults' professionalism formation.

According to W. Gieseke (2010), research organizations in the field of adult education should have a documentation department that constantly evaluates statistics and staffing data in both autonomous and institutionalized adult education providers. Such organizations must simultaneously include in their field of experience empirical research in the andragogy training, and an equally wide range of concepts of further education for all participants in the educational process i.e. both teachers and students. According to W. Gieseke (2010), in adult education and continuing education, professionalization means «program support for fulltime teaching» (p. 385). Professionalization, as well as professionalism «means competence in individual activities and in processes related to the differentiation of scientifically sound professions, which includes a specialist (teacher) working with adults» (p. 386). In the context of adult education and continuing education, teacher professionalism refers to «the ability to solve complex problems within a managerial task at a high scientific and theoretical level» (Gieseke, 2008, p.45).

In the research of Christina Buschle and Rudolf Tippelt we find the view that the pedagogical professionalism framework has changed and expanded, and this directly affects the training and competence requirements of adult education. They emphasize that professionalization is a "structural requirement in the modernization process» (Buschle \& Tippelt, 2012). They explain this fact in detail, referring to the 
expansion of the institutions network for adult education and the adult contingent. This statement is ambivalent, as on the one hand, it highlights the need for professional training in adult education, and on the other it complicates this process with a growing number of limiting factors and additional requirements. Researchers note a growing trend of objective and subjective requirements for adult education professionals to obtain higher qualifications, confirmation, validation and certification of andragogical competencies.

Also, according to researchers, the cornerstone of the professionalism of teachers for adults, and accordingly the starting point of the process of its preparation and confirmation of qualifications, should be the focus on the needs of students (target groups). It should be noted that similar statements can be found in other German scientists (A. v. Hippel, L. Hummel, V. Thalhammer, E. Terhart, K. Tillmann, etc.), which is evidence of active research and discussion of staff training in the field of adult education, as well as attempts to agree on key points and approaches to this process organization.

Gradually, in the framework of the outlined scientific research, the ideas of the academic training substantiation of specialists for adult education as a separate direction in the professionalization of the research field are singled out. Thus, it is necessary to realize the difference between the professionalism in adult educators, formed on the background of professional biography, i.e. in practice, and efforts to academize adult education, because the transfer of andragogy to academy shows recognition and growing role of adult education at all levels of society.

Regina Egetenmeyer, Susanne Lattke and Ingeborg Schuessler launched a discussion in this field of research on a new era of andragogy professionalism and the adult education professionalization. Scholars highlighted the historical traditions, experience, basics, process and content of specialist training in academia, including universities. In particular, R. Egetenmeyer and I. Schuessler analyzed the current state of academic professionalization in adult education and concluded that it focuses on proposals for university studies as a structural perspective, on the development of adult educators' professionalism through the subject mastery. The training of an adult education specialist is a reflection of educational policy and social programs «targeted» to obtain such specialists, and from the other side, it dictates trends and influences the educational, professional and socio-political space of the country where it is implemented (Egetenmeyer, 2019; Egetenmeyer \& Schüßler, 2014; Schuessler \& Egetenmeyer, 2016).

It is worth noting that the issue of professionalization of adult education and training for the industry is not only the subject of research and reflection of scientists, but also has already got a wide public response for 50 years. Thus, the German Society for Adult Education (Deutscher Volkshochschul-Verband) in the 1970s, supported by laws on adult education in the countries, made the profession and qualification of staff its most important task. Other associations and churches have followed this example. However, there was no need to talk about professionalization within the associations. It was about the employee, his/her tasks, qualifications within the association, the consistent achievement of basic professionalism. Hans Tietgens, director of the pedagogical department of the German Association for Adult Education until 1991, used the term "professionalism» only in 1988 (Gieseke, 2008) and meant competent, customer-oriented and responsible action. At the same time, it should be emphasized that H. Tietgens since late 1950s, W. Schulenberg in 1972 and R. Vath in 1975 and 1994 in their works argued step by step to theoretically comprehend the process of teaching adults professionalization (Tietgens, 1981, 1988, 1998; Schulenberg, 1972; Vath, 1975, 1994).

For adult / continuing education, the theoretical discourse of professionalization and professionalism, as well as the concept of profession, have been used since the 1960s as a structuring concept for generating professions in the context of institutionalization, i.e. structure-forming concept (Schulenberg, 1972). In general, the professionalization theoretical areas that have been largely used for adult / continuing education in Germany since then are:

- professionalization as a consistent effect of scientific substantiation of all activities in the relevant field (adult education / continuing education) to support them with relevant specialized education; 
- professionalization is aimed at gaining a social position in order to ensure interpretive influence and dominance in certain areas of activity;

- professionalization is aimed at acquiring professional competence on a scientific basis and autonomy of actions that are embedded in ethical obligations to the appropriate connection to counter the requirements of providers and markets through special standards.

Professionalism as a phenomenon introduced by H.Tietgens in the 1980s also describes competent pedagogical actions in adult education / continuing education regardless of the employment relationship. This means the ability to research, conceptualize and support complex teaching / learning requirements and structure requirements in this area within a leadership task at the highest scientific and theoretical levels, to evaluate concepts and focus on learners and their needs and requests. «In order to meet these requirements, it is necessary to have extensive knowledge of the entire field of continuing education, as well as be able to analyse in detail the situation and complex program and organizational structures in this area. Professionalism is based on fundamental knowledge that is assessed through experience. It is not based on a planned process, but on specific solutions to problems, interpretations, diagnoses, which must be made within the framework of individual responsibility and lead to action» (Gieseke, 2005, p.12). Similarly, Ditter Nittel (2000) presents a comprehensive analysis of professional development in continuing education: «In general, professionalism is not a 'state' that can be achieved or aquired, but rather a fleeting professional achievement that must be re-established each time depending on the situation» (p. 85), based on constant, including academic, continuing education.

In the 1990s, the concept of the profession was gradually deprived of claims to ethical criteria and focus on social values (Dewe, Ferchhoff \& Radtke, 1992). In neoliberalism, costs are minimized through rationalization, focus on efficiency, and savings by streamlining professional activity through templates and patterns. A professional is one who works smoothly, quickly and without losses. In addition, the concept of management and networking based on a bottom-up approach is becoming increas- ingly important (for example, the leadership institutionalization through these concepts).

At the same time, German researchers pay great attention to substantiating the scientific basis of professionalization as the basis for the specialist activities in adult education and the industry functioning in general. According to $S$. Kade, there is no profession without scientific justification (Kade, 2006). As for the concept of the profession, nowadays in the field of adult education there are considerations to abandon it or put it in the background, as well as to establish a new proximity to other related disciplines of educational science in lifelong learning and talk about different social worlds (Tippelt \& Nittel, 2014).

Conclusions. Thus, professionalization in adult education in Germany has gone from construction (first phase) to deconstruction (second phase) and market development according to new aspects of efficiency (third phase). At present, the fourth stage is the reorganization of institutional, scientific and ethical requirements for educational work, in which the interests of participants and carefully structured models are (should be) balanced (Gieseke, 2015). For continuing education, professionalism means the ability to solve complex problems within a managerial task at a high scientific and theoretical level, where each individual is directly related to the person.

Deviation from the state claim to the understanding of adult education as a service does not reduce professional requirements, but, on the contrary, increases the requirements for persons working in dynamically developing institutions. This interpretation is supported by modern definitions and descriptions of professionalism. An expanded concept of professionalism is being formed, which is determined by a high level of knowledge at the scientific level, well-founded developed knowledge and skills, systematic compliance with adult education current rules and canons, special ideals of work and efficiency with holistic solutions, comprehensive sense of responsibility.

However, despite all the rationalization and optimization of knowledge, the basic theory is that the intertwining of science and practice in professional activities is inevitable. Adequacy should always be brought together through case-by-case analysis in collaborative research. 
This procedure also requires scientific analysis in the future. Then paradoxes always have an effect, because for the creative development of society, a person's stubbornness requires his/her will, and the subjective factor plays a formative role in successful professional action. Therefore, there is a need to study and take in- to account the antinomies and paradoxes that arise in all pedagogical organizations, and not only in adult education / continuing education, and scientific and practical evidence that professional activity is in their awareness and balance.

\section{REFERENCES}

Ambos, I., Koscheck, St., \& Martin, A. (2014). Personalgewinnung von Weiterbildungsanbietern. Wbmonitor. URL: http://www.bibb.de/dokumente/pdf/a22 wbmonitor ergebnisbericht umirage 2014.pdf.

Arnold, R., \& Lermen, M. (2012). Professionalisierungsverhalten und Wissenschaftliche Weiterbildung im Kontext des Lebenslangen Lernens. In R. Egetenmeyer \& I. Schüßler (Hrsg.), Akademische Professionalisierung in der Erwachsenenbildung/Weiterbildung (S. 201-212). Baltmannsweiler: UTB.

Buschle, C., \& Tippelt, R. (2012). Multiprofessionalität, Diversifizierung und Höherqualifizierung als Herausforderungen pädagogischer Professionalität. In W. Gieseke, E. Nuissl, \& I. Schüßler (Hrsg.), Reflexionen zur Selbstbildung. Festschrift für Rolf Arnold. Theorie und Praxis in der Erwachsenenbildung (S. 189-209). Bielefeld: Bertelsmann.

Dewe, B., Ferchhoff, W., \& Radtke, F.-O. (1992). Das Professionswissen von Pädagogen. Ein wissenstheoretischer Rekonstruktionsversuch. In Dies. (Hrsg.), Erziehen als Profession. Zur Logik professionellen Handelns in pädagogischen Feldern (S. 70-91). Opladen.

Egetenmeyer, R. (2019). Adult Education, Professionalisation and Lifelong Learning Policies. In: Journal of Adult and Continuing Education. No 1. Vol. 25. pp. 3-6. URL: https://doi.org/10.1177/1477971419847387.

Egetenmeyer, R., \& Schüßler, I. (2014). Empirische Befunde zur Akademischen Professionalisierung in der Erwachsenenbildung. Strukturelle und subjektive Faktoren der Professionalitätsentwicklung an Hochschulen. Hessische Blätter für Volksbildung, 1(64), 29-42.

Gieseke, W. (2005). Professionalität - Paradoxien und Widerspruche in der Erwachsenenbildung/ Weiterbildung. In M. Gutknecht-Gmeiner (Hrsg.), Das Richtige richtig tun. Professionalität in der Erwachsenenbildung. Dokumentation der 47. Salzburger Gespräche für Leiterinnen und Leiter in der Erwachsenenbildung (S. 12-33). Wien: Verband Österreichischer Volkshochschulen.

Gieseke, W. (2008). Zwischen Verberuflichung und Professionalität: 50 Jahre Support für die Profession Erwachsenenbildung. In E. Nuissl (Hrsg.), 50 Jahre für die Erwachsenenbildung (S. 45-62). Bielefeld: wbv.

Gieseke, W. (2010). Professionalisierung in der Erwachsenenbildung/Weiterbildung. In R. Tippelt \& A. von Hippel (Hrsg), Handbuch Erwachsenenbildung/Weiterbildung (4. Aufl., S. 385-403). Wiesbaden: VS Verlag für Sozialwissenschaften.

Hartz, S. (2004). Biographizität und Professionalität. Wiesbaden: VS Verlag für Sozialwissenschaften.

Heidenreich, M. (1999). Berufskonstruktion und Professionalisierung Erträge der soziologischen Forschung. In H. Apel, K. Horn, P. Lundgreen, U. Sandfuchs (Hg.), Professionalisierung pädagogischer Berufe im historischen Prozeß (S. 35-58). Bad HeilbrunnObb.

Kade, J. (2006). Kommunikation und Bewusstsein - ein Blick auf das Fach aus systemtheoretischer Perspektive. In G. Wiesner, C. Zeuner \& H. J. Forneck (Hrsg.), Empirische Forschung und Theoriebildung in der Erwachsenenbildung (S. 19-26). Baltmannsweiler: Schneider Hohengehren.

Klingovsky, U. (2012). Professionalisierung in der wissenschaftlichen Weiterbildung. Hessische Blätter für Volksbildung, 2, 143-151.

Koscheck, St., Weiland, M., \& Ditschek, E. J. (2012). Wbmonitor. Klima und Strukturen der Weiterbildungslandschaft - Zentrale Ergebnisse im Überblick. URL: http://www.bibb.de/dokumente/pdf/ wbmonitor Ergebnisbericht Umfrage 2012.pdf.

Kraft, S. (2007). Die Situation der Beschäftigten in der Weiterbildung - ein Blick in die Realität und Perspektiven für die Zukunft. Außerschulische Bildung, 38(2), 188-195.

Kraft, S., Seitter, W., \& Kollewe, L. (2009). Professionalitätsentwicklung des Weiterbildungspersonals. Bielefeld: W. Bertelsmann.

Kühn, C., Brandt, P., Robak, S., Pohlmann, C., \& Dust, M. (2015). Funktionsprofile, Weiterbildungsverhalten und Zertifizierungsinteressen des niedersächsischen Weiterbildungspersonals. URL: http://www.diebonn.de/doks/2015-weiterbildungsverhalten-01.pdf.

Meisel, K., \& Dollhausen, K. (2006). Erwachsenenpädagogische Qualität als Ziel des Qualitätsmanagements. In W. Markert (Hrsg.), Qualität des beruflichen Lernens in der Weiterbildung (S. 57-67). Baltmannsweiler: Schneider Verlag. 
Mieg, H. A. (2006). Professionalisierung. In F. Rauner (Hrsg.), Handbuch Berufsbildungsforschung (S. 343350). Bielefeld: wbv.

Mieg, H., \& Pfadenhauer, M. (Hrsg.). (2003). Professionelle Leistung - Professional Performance. Konstanz: UVK.

Nittel, D. (2000). Von der Mission zur Profession. Bielefeld: wbv.

Schmidt-Lauff, S. (2008). Zeit für Bildung im Erwachsenenalter Interdisziplinäre und empirische Zugänge. Habilitation. Berlin: Waxmann.

Schmidt-Lauff, S., \& Gieseke, W. (2014). Professionellen Sein im Referenzkontext Erwachsenenbildung. In M. Schwarz, W. Ferchhoff \& R. Vollbrecht (Hrsg.), Professionalität: Wissen - Kontext. Sozialwissenschaftliche Analysen und pädagogische Reflexionen zur Struktur bildenden und beratenden Handelns. Festschrift für Prof. Bernd Dewe (S. 519-535). Bad Heilbrunn: Julius Klinkhardt.

Schuessler, I., \& Egetenmeyer, R. (2016). Akademische Professionalisierung - zur Situation der Studiengänge in der Erwachsenenbildung/Weiterbildung in Deutschland. In R. Tippelt, A. von Hippel (Eds.), Handbuch Erwachsenenbildung /Weiterbildung (pp. 1-18). Springer Reference Sozialwissenschaften. DOI 10.1007/978-3-531-20001-9_53-1.

Schulenberg, W. (1972). Zur Professionalisierung der Erwachsenenbildung. Braunschweig: Westermann.

Tietgens, H. (1981). Die Erwachsenenbildung. München: Juventa.

Tietgens, H. (1988). Professionalität in der Erwachsenenbildung. In W. Gieseke et al. (Hrsg.), Professionalität und Professionalisierung (S. 11-27). Wiesbaden: VS Verlag für Sozialwissenschaften.

Tietgens, H. (1998). Interpretationswerkstatt im Kontext der Forschung und als Medium der Fortbildung. In R. Arnold et al. (Hrsg.), Lehren und Lernen im Modus der Auslegung. Erwachsenenbildung zwischen Wissensvermittlung, Deutungslernen und Aneignung (S. 8-21). Baltmannsweiler: UTB.

Tippelt, R., \& Nittel, D. (2014). Die Professionalisierung von Erziehung und Bildung im Spannungsverhältnis zwischen einem pädagogisch organisierten oder einem pädagogisch verfassten System des lebenslangen Lernens. In D. Nittel, J. Schutz \& R. Tippelt (Hrsg.), Pädagogische Arbeit im System lebenslangen Lernens - Ergebnisse komparativer Berufsgruppenforschung (S. 255-268). Weinheim: Beltz.

Vath, R. (1975). Die Professionalisierungstendenz in der Erwachsenenbildung. Diss. Regensburg.

Vath, R. (1994). Professionalisierung in der Erwachsenenbildung. In E. Schmitz \& H. Tietgens (Hrsg.), Enzyklopädie Erziehungswissenschaft (Erwachsenenbildung, Bd. 11, S. 303-315). Stuttgart: Klett Verlag für Wissen und Bildung.

Марія Гуляєва, кандидат педагогічних наук, асистент кафедри педагогіки та соціальної роботи Чернівецького національного університету імені Юрія Федьковича.

Mariia Huliaieva, PhD in Pedagogy, Assistant Professor of Department of Pedagogy and Social Work, Yurii Fedkovych Chernivtsi National University.

E-mail: m.gulyaeva@chnu.edu.ua ORCID ID 0000-0003-2963-6881 